\title{
RIBOSURIA IN MUSCULAR DYSTROPHY
}

\section{BY}

\author{
W. B. MATTHEWS and M. J. H. SMITH
}

From King's College Hospital and Medical School, Denmark Hill, London

Ribosuria as a characteristic feature of muscular dystrophy was reported by Minot, Frank, and Dziewiatkowski (1949). The ribosuria was detected by a positive reduction with Benedict's qualitative reagent on prolonged heating and the sugar identified by the preparation of its osazone. A test for muscular dystrophy based on the microscopical appearance of this osazone was devised by Orr and Minot (1952). It was claimed that this reaction for ribose was positive in all cases of progressive muscular dystrophy, dystrophia myotonica, myotonia congenita and amyotonia congenita, and in some cases of poliomyelitis in the febrile stage, but was negative in a variety of other conditions such as myasthenia gravis and progressive muscular atrophy.

We therefore examined the urine of patients suffering from a variety of myopathic disorders for ribose by a sensitive and specific paper chromatographic technique.

\section{Methods}

Urine Specimens.-Twenty-four hour collections were made from ward patients and early morning specimens obtained from out-patients; no preservative was employed. Each urine was tested by heating 8 drops for 45 minutes in a boiling water-bath with $5 \mathrm{ml}$. of Benedict's qualitative reagent and by the paper chromatographic technique described below. These tests were performed on each specimen when it was received in the laboratory and after it had been allowed to stand for 24 hours at room temperature. The two tests were repeated after the addition of $20 \mathrm{ml}$. concentrated $\mathrm{HCl}$ and a further 24 hours' standing.

Paper Chromatographic Method for Ribose.-A descending method using one dimension strips of Whatman No. 1 filter paper and a n-butanol-acetic acidwater mixture was employed (Horrocks and Manning, 1949). Each chromatogram was run for 24 hours and the spraying reagent was aniline hydrogen phthalate $(0.9 \mathrm{ml}$. of redistilled aniline dissolved in $100 \mathrm{ml}$. of $0 \cdot 1 \mathrm{M}$ phthalic acid). Glucose and ribose were used as marker substances, the $R f$ values being $0 \cdot 19$ and 0.33 respectively (uncorrected for temperature). The spraying reagent gave a yellow-brown spot with glucose and a rèd-brown spot with ribose. The spots exhibited intense greenish-blue fluorescence under ultra-violet light (Consden and Stanier, 1952). A "hanovia chromalite" lamp was used as the light source. The intensity of this fluorescence was such that it was easily possible to detect $5 \mu \mathrm{g}$. of the sugars on the chromatograms. Quantities of urine up to $100 \mu \mathrm{l}$. were used in each run so that the sensitivity of the method was at least $5 \mu \mathrm{g}$. in $100 \mu \mathrm{l}$. of urine. Therefore if no ribose was detected on the chromatogram the urine specimen must have contained less than $5 \mathrm{mg}$. ribose per $100 \mathrm{ml}$. Assuming an average daily urine volume of $1,500 \mathrm{ml}$. less than $75 \mathrm{mg}$. in 24 hours of ribose were excreted.

CLINICAL MATERIAL

\begin{tabular}{|c|c|c|}
\hline Condition & Type & $\begin{array}{l}\text { No. of } \\
\text { Cases }\end{array}$ \\
\hline $\begin{array}{l}\text { Progressive muscular } \\
\text { dystrophy }\end{array}$ & $\begin{array}{l}\text { (a) Pseudohypertrophic muscular } \\
\text { dystrophy } \\
\text { (b) Facioscapulohumeral muscular } \\
\text { dystrophy ,; } \\
\text { (c) "Late forms " }\end{array}$ & $1 \longdiv { c }$ \\
\hline Dystrophia myotonica & & 2 \\
\hline Ocular myopathy & Kiloh and Nevin (1951) & 1 \\
\hline Poliomyelitis & Febrile stage & 2 \\
\hline
\end{tabular}

\section{Results and Discussion}

In only two urines out of 11 examined was any reduction obtained on testing with Benedict's qualitative reagent. In no case was ribose detected on a paper chromatogram and therefore less than $5 \mathrm{mg}$. per $100 \mathrm{ml}$. of ribose was present in the urine samples. The two specimens which reduced Benedict's qualitative reagent and were from patients with muscular dystrophy and poliomyelitis respectively, when chromatographed on paper showed the presence of glucose only. The failure to demonstrate ribose, even after the urine was allowed to stand, is important because Minot and others (1949) considered that in cases of muscular dystrophy the ribose was excreted as a phosphate complex which became converted to free ribose on standing.

The results show that the excretion of significant amounts, i.e., more than $5 \mathrm{mg}$. per $100 \mathrm{ml}$., of ribose 
in the urine did not occur in the patients we have studied. We do not consider therefore that ribosuria is a characteristic feature of muscular dystrophy and allied diseases, and a test based on its alleged association with these conditions is of no value in differential diagnosis.

\section{Summary}

The urine of patients suffering from muscular dystrophy and certain allied conditions has been examined for ribose by a sensitive and specific paper chromatographic technique. Ribose was not detected in the urine specimens and it is concluded that ribosuria is not a characteristic feature of this group of diseases.

We wish to thank Miss E. Quilley for technical assistance, the physicians of King's College Hospital and of the Western Hospital for permission to report on their patients, and the Board of Governors of King's College Hospital for a grant to one of us (M.J.H.S.) towards the cost of the work.

\section{REFERENCES}

Consden, R., and Stanier, W. M. (1952). Nature, Lond., 169, 783. Horrocks, R. H., and Manning, G. B. (1949). Lancet, 1, 1042. Kiloh, L. G., and Nevin, S. (1951). Brain, 74, 115.

Minot, A. S., Frank, H., and Dziewiatkowski, D. (1949). Arch. Biochem., 20, 394.

Orr, W. F., and Minot, A. S. (1952). Arch. Neurol. Psychiat Chicago, 67, 483. 